\title{
FUTURE CONSIDERATIONS IN THE SHIPMENT OF PUTONIUM
}

L.W. Brackenbush, C. L. Brown and L.G. Faust

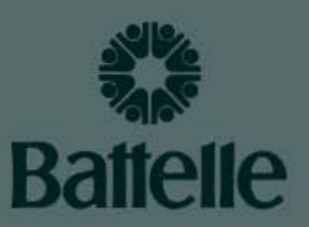

Pacific Northwest Laboratories

Richland, Washington 99352

OCTOBER 1974

Prepared for the U.S. Atomic Energy

Commission under Contract AT(45-1):1830 
NOTICE

The report was prepared as an account of work sponsored by the United States Government. Neither the United States nor the United States Atomic Energy Commission, nor any of their employees, nor any of their contractors, subcontractors, or their employees, makes any warranty, express or implied, or assumes any legal liability or responsibility for the accuracy, completeness or usefulness of any information, apparatus, product or process disclosed, or represents that its use would not infringe privately owned rights.

\author{
PACIFIC NORTHWEST LABORATORY \\ operated by \\ BATTELLE \\ for the \\ U.S. ATOMIC ENERGY COMMISSION \\ Under Contract AT(45-1)-1830
}

\author{
Printed in the United States of America \\ Available from \\ National Technical Information Service \\ U.S. Department of Commerce \\ 5285 Port Royal Road \\ Springfield, Virginia 22151 \\ Price: Printed Copy \$4.00: Microfiche \$1.45
}


UC-71, Transportation of Property and Nuclear Materials

FUTURE CONSIDERATIONS IN THE SHIPMENT OF PLUTONIUM

by

LW Brackenbush

CL Brown

LG Faust

October 1974

BATTELLE

PACIFIC NORTHWEST LABORATORIES

Richland, Washington 99352 


\section{EXECUTIVE SUMMARY}

By 1985, plutonium production from LWR's will increase from 2 metric tonnes (MT)/year to about 43 MT/year. The specific activity of this plutonium will be a factor of about four higher than todays production grade plutonium. At the same time heat generation per gram of plutonium will increase by a factor of about four.

Based on the data presented, it is concluded that heat loads and radiation levels associated with high exposure plutonium will require many changes in future shipping practices for this type materials. Incorporation of neutron shielding in packaging is expected to be required as will redesign to accomodate increased heat loads. Moreover, safeguards considerations are expected to bring about the use of specially designed trucks for plutonium transport. These trucks will incorporate special features to further help prevent theft while in transit.

From the viewpoint of criticality safety, limitations on future package and truck loadings should be no more restrictive than at present. In some instances, criticality safety limitations may be relaxed slightly by taking credit for the lower fissile content of high exposure plutonium.

An estimate of how much plutonium could be shipped in a truck, under the above mentioned conditions, was found to be about 1.5 MT plutonium (as $\mathrm{PuO}_{2}$ ) per truck. This quantity would represent about one months production from a large separations plant.

In the more distant future, one possible direction which might tend to simplify some of the transport related problems is the nuclear park concept. Under this concept onsite facilities would preclude the transportation of plutonium over long distances. Nuclear reactors, the separation plant, and the fuel fabrication facilities, with emphasis on the latter two, would be located on one site and plutonium would be transported from one facility to another without actually entering the public transportation sys tem. 
CONTENTS

Page

EXECUTIVE SUMMARY. . . . . . . . . . . . i

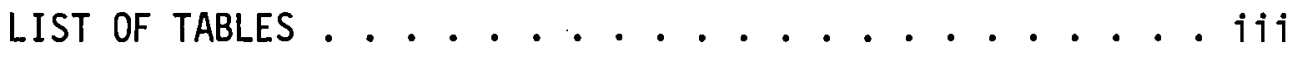

LIST OF FIGURES. . . . . . . . . . . . . ii1

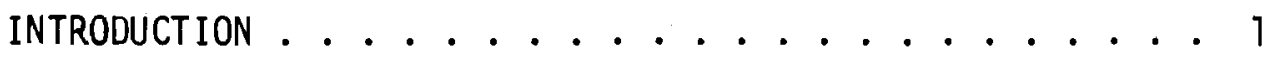

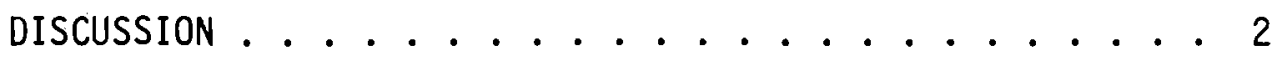

LIMITATIONS ON FORM OF PLUTONIUM SHIPPED IN THE FUTURE . 2

FACTORS THAT AFFECT FUTURE PLUTONIUM PACKAGING DESIGN. - 2

Expected Changes in Isotopic Composition. . . . . 2

Heat Generation . . . . . . . . . 3

Dose Rate . . . . . . . . . . . . 4

Safeguards Considerations ......... 8

CRITICALITY SAFETY CONSIDERATIONS. . . . . . . 8

ESTIMATE OF TRUCK CAPACITY FOR FUTURE PUO,

POWDER SHIPMENTS .............. 8

REFERENCES ................. 12 


\section{LIST OF TABLES}

1 Isotopic Composition and Quantity of LWR-Produced

Plutonium Produced. .............. 3

2 Specific Activity of Typical LWR-Produced Plutonium . . 3

3 Heat Generation and Maximum Masses of $\mathrm{PuO}_{2}$ for 30 Watt Containers............ 4

4 Estimated Neutron Yield From Plutonium Isotopes . . .. 5

5 Neutron Dose Equivalent Rates . . . . . . . . . 6

6 Estimate of Allowable $\mathrm{PuO}_{2}$ Package Loading For 108 Packages Shipped As Fissile Class III ........ 11

\section{LIST OF FIGURES}

1 Dose Equivalent Rate from a $4 \times 10$ Array of Shipping Containers with $2.6 \mathrm{~kg}$ of $1980 \mathrm{Pu}$ or $10 \mathrm{~kg}$ of

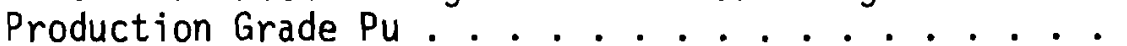




\section{Future Considerations in the Shipment of Plutonium}

LW Brackenbush, CL Brown, and LG Faust

\section{INTRODUCTION}

At the present time, the manufacture of $\mathrm{PuO}_{2}-\mathrm{UO}_{2}$ reactor fuels requires the shipment of plutonium from a chemical reprocessor to a reactor fuel fabricator and then on to either storage or the reactor. More often than not these facilities have been far removed from one another.

Until now, the characteristics of this plutonium and the quantities requiring transportation have afforded no special problems in shipment. In the near future, however, this picture will change considerably.

First, the characteristics of nuclear power reactor fuel grade plutonium will become more evident. Problems presented by higher radiation levels and thermal output will make present packaging designs obsolete. Also, safeguards considerations may require further design restrictions.

Second, the incentive for more sophisticated packaging design will be aggravated by the fact that the production rate of high exposure plutonium from power reactors will steadily increase. By 1985, the amount of plutonium requiring shipment will have increased from about 2 metric tonnes (MT)/ year to about 43 MT/year. As these larger quantites become available and require shipment, more emphas is will be placed on higher package loadings and a greater number of packages per transport vehicle.

The objective of this paper is to give added perspective to these problems and hopefully provide a firmer basis for planning new or improved concepts for future plutonium transportation. Problems associated with the shipment of plutonium in solid form (assumed to be $\mathrm{PuO}_{2}$ ) are emphasized since the shipment of solutions will be discontinued in less than four years. (1) 
DISCUSSION

\section{LIMITATIONS ON FORM OF PLUTONIUM SHIPPED IN THE FUTURE}

Plutonium is currently being shipped in a variety of forms. The most common forms are $\mathrm{PuO}_{2}$ powder, $\mathrm{Pu}\left(\mathrm{NO}_{3}\right)_{4}$ solution, and plutonium metal. A recent change in Federal regulations now requires that after June 17, 1978, plutonium in excess of 20 curies be shipped only in solid form. ${ }^{(1)}$ This means that after that date, the shipment of $\mathrm{Pu}\left(\mathrm{NO}_{3}\right)_{4}$ solution will be prohibited.

Because of this impending new requirement, between now and $1978 \mathrm{Pu}\left(\mathrm{NO}_{3}\right)_{4}$ solution packaging and shipping technology will be phased out of the transportation cycle. Concurrently during this period, emphasis will be placed on improving packaging technology for plutonium in solid form. For high exposure plutonium the principal solid form foreseen at present is $\mathrm{PuO}_{2}$ powder.

Other solid plutonium forms that may be more manageable than $\mathrm{PuO}_{2}$ powder are being investigated. One such study is investigating solid forms of plutonium nitrate. (2) The objective of this study is to determine if plutonium nitrate in powder form can be stored and shipped safely, made economically and is readily soluble in nitric acid. If so, then plutonium nitrate powder may be superior to $\mathrm{PuO}_{2}$ as a feed material for plutonium fuel fabrication. Compounds currently under investigation are $\mathrm{Pu}\left(\mathrm{NO}_{3}\right)_{4} \cdot \mathrm{XH}_{2} \mathrm{O}$, $\mathrm{K}_{2} \mathrm{Pu}\left(\mathrm{NO}_{3}\right)_{6}$ and $\left(\mathrm{NH}_{4}\right)_{2} \mathrm{Pu}\left(\mathrm{NO}_{3}\right)_{6}$.

FACTORS THAT AFFECT FUTURE PLUTONIUM PACKAGING DESIGN

\section{Expected Changes In Isotopic Composition}

Up until the present time, most of the plutonium encountered by the nuclear industry has been typically about $90 \mathrm{wt} \%$ or greater ${ }^{239} \mathrm{Pu}$ and about 6 to $8 \mathrm{wt} \%{ }^{240} \mathrm{Pu}$. This material has been referred to variously as "weapons grade", "production grade" or "low exposure" plutonium. If planned fuel exposure goals are met, the plutonium that will be available from commercial Light water Reactors (LWR's) will be considerably different. This reactor grade or "high exposure" plutonium is for present purposes defined as any plutonium containing $80 \mathrm{wt} \%$ or less ${ }^{239} \mathrm{Pu}$. 
The calculated isotopic compositions of the LWR produced plutonium for the years 1975, 1980 and 1985 and the expected quantities produced per year are summarized in Table 1. These values are considered to be typical although they are averages over all LWR's, and it should be emphasized that as such it is rather improbable that anyone would ever encounter these exact compositions. It must also be emphasized that these values could change due to startup delays, unscheduled outages, fuel performance, more or less frequent recycle, etc., and as a consequence should be considered primarily as illustrative values.

\section{Table 1 - Isotopic Composition and Quantity of LWR-Produced Plutonium Produced}

\begin{tabular}{|c|c|c|c|c|c|c|c|}
\hline & \multicolumn{6}{|c|}{ Pu Isotope, wt\% } & \multirow{2}{*}{$\begin{array}{r}\text { Quantity, } \\
\mathrm{kg} \text { Pu/year } \\
\end{array}$} \\
\hline & ${ }^{236} \mathrm{Pu}$ & ${ }^{238} \mathrm{Pu}$ & $239 \mathrm{Pu}$ & ${ }^{240} \mathrm{Pu}$ & ${ }^{24 T_{\mathrm{Pu}}}$ & ${ }^{242} \mathrm{Pu}$ & \\
\hline 7 & $5 \times 10^{-6}$ & 0.9 & 65.6 & 21.8 & 9.0 & 2.7 & 2,600 \\
\hline 80 & $7.3 \times 10^{-6}$ & 1.5 & 58.1 & 24.1 & 11.4 & 4.9 & 18,000 \\
\hline 1985 & $6.5 \times 10^{-6}$ & 1.6 & 54.7 & 24.7 & 12.2 & 6.7 & 43,000 \\
\hline
\end{tabular}

The specific activities of the plutonium compositions given in Table 1, including typical production grade plutonium for comparison purposes, are summarized in Table 2.

Table 2 - Specific Activity of Typical LWR-Produced Plutonium

\begin{tabular}{cccc} 
& \multicolumn{3}{l}{ Specific Activity, $\mathrm{Ci} / \mathrm{g}$} \\
Production Grade & Alpha & Beta & Total \\
1975 & 0.07 & 3.0 & 3.0 \\
1980 & 0.25 & 8.9 & 9.2 \\
1985 & 0.36 & 11.3 & 11.7 \\
& 0.38 & 12.1 & 12.5
\end{tabular}

Heat Generation

The increase in specific activity by a factor of about four effects at least two parameters that should be of prime interest to those responsible for shipping. These are heat generation and dose rates. 
Present practice in shipping plutonium oxide is based on an inner sealed metal can within an inner, gasketed metal container. That unit is then supported within a metal drum of from 10 to 110 gallon capacity, by thermal and shock insulating material, e.g., vermiculite, fiberboard, etc. This whole package is presently limited to a heat generation of 30 watts at Hanford. Based on the data from Table 2, the heat generation and total allowable loadings/container are summarized in Table 3.

\begin{tabular}{|c|c|c|}
\hline Year & Heat, w/kg & Mass, kg \\
\hline Production Grade & 3 & 10 \\
\hline 1975 & 8.2 & 3.7 \\
\hline 1980 & 11.6 & 2.6 \\
\hline 1985 & 12.2 & 2.45 \\
\hline
\end{tabular}

Shipment of quantities as small as $2.4 \mathrm{~kg}$ is not likely to be either practical or economical. As a consequence, current designs are considered to be no longer suitable and new designs with improved heat dissipation characteristics will surely be required in order to permit shipment of reasonable quantities of reactor grade plutonium.

\section{Dose Rate}

The neutron dose equivalent rates, $H(\mathrm{mrem} / \mathrm{hr})$, as sociated with current containers and mass loadings, as given in Table 3 , were calculated using data presented in Table 4 and the formula:

$$
H=9.7 \times 10^{-3} \mathrm{~s} / \mathrm{r}^{2}
$$

where $S=$ total neutron emission rate in neutrons/sec, and

$r=$ distance from center of the mass in $\mathrm{cm}$.

It has been found that equation (1) yields results to within $\pm 20 \%$ for $\mathrm{PuO}_{2}$ containers containing up to $5 \mathrm{~kg}$ of loose powder $\left(\rho \leq 4 \mathrm{~g} / \mathrm{cm}^{3}\right)$ because they 
approximate a point source and little or no induced fission occurs. The dose equivalent rate from an array of containers could also be calculated assuming each container to be a point source, using equation (1) and summing over the total array with perhaps some slight increase for induced fission.

Table 4 - Estimated Neutron Yield From Plutonium Isotopes

\begin{tabular}{|c|c|c|c|}
\hline \multirow[b]{2}{*}{ Nuclide } & \multicolumn{3}{|c|}{ Neutrons/sec-gm } \\
\hline & Spontaneous Fission & $\underline{0(\alpha, n)}$ & $\mathrm{PuO}_{2}$ Total \\
\hline${ }^{236} \mathrm{Pu}$ & $3.7 \times 10^{4}$ & $4.3 \times 10^{5}$ & $4.7 \times 10^{5}$ \\
\hline${ }^{238} \mathrm{Pu}$ & $2.6 \times 10^{3}$ & $1.4 \times 10^{4}$ & $1.7 \times 10^{4}$ \\
\hline${ }^{239} \mathrm{Pu}$ & $3.0 \times 10^{-2}$ & $4.5 \times 10^{1}$ & $4.5 \times 10^{1}$ \\
\hline${ }^{240} \mathrm{Pu}$ & $1.0 \times 10^{3}$ & $1.7 \times 10^{2}$ & $1.2 \times 10^{3}$ \\
\hline $241_{\mathrm{Pu}}$ & -- & 1.8 & 1.8 \\
\hline${ }^{242} \mathrm{Pu}$ & $1.7 \times 10^{3}$ & 2.7 & $1.7 \times 10^{3}$ \\
\hline${ }^{241_{A m}}(a)$ & $8.0 \times 10^{-1}$ & $2.6 \times 10^{3}$ & $2.6 \times 10^{3}$ \\
\hline
\end{tabular}

(a) The build in of ${ }^{241} \mathrm{Am}$ from the decay of ${ }^{241} \mathrm{Pu}$ can be predicted from $N_{A m}(t)=N_{P u}(0) x-1.03\left(e^{-0.0462 t}-e^{-0.0016 t)}\right.$,

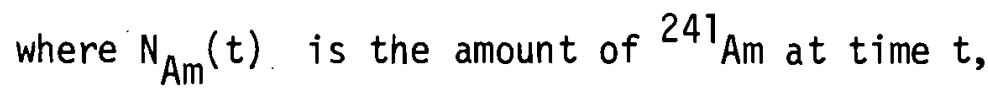
$\mathrm{N}_{\mathrm{Pu}}(0)$ is the amount of ${ }^{241} \mathrm{Pu}$ at the time of chemical
separation, and $t \quad$ is the time in years since chemical separation of the plutonium

The neutron dose equivalent rates at three feet from the surface of the shipping containers are presented in Table 5 for the maximum amount of plutonium allowed for a 30 watt heat load. 
Table 5 - Neutron Dose Equivalent Rates

\begin{tabular}{|c|c|c|}
\hline Year & $\underline{\mathrm{s}, \mathrm{n} / \mathrm{sec}-\mathrm{kg} \mathrm{PuO}_{2}}$ & $\begin{array}{l}\mathrm{H}, \mathrm{mrem} / \mathrm{hr} \text { (for Given } \\
\text { Mass Loading at } 3 \text { Feet) }\end{array}$ \\
\hline Production Grade & $1.2 \times 10^{5}$ & 1.4 \\
\hline 1975 & $4.9 \times 10^{5}$ & 2.1 \\
\hline 1980 & $6.5 \times 10^{5}$ & 2.2 \\
\hline 1985 & $7.1 \times 10^{5}$ & 2.0 \\
\hline
\end{tabular}

There is a photon dose rate also associated with this material; however, because of the number of unknowns such as type of metal, thickness, etc., it is very difficult to calculate. The photon dose rate is also a function of the "age" of the plutonium, i.e., the time since it was last purified. [The neutron dose rate also changes with age but not nearly as fast and can usually be ignored for reasonable times.] If it can be assumed that the material is one-year old, and that the containers are steel with a total thickness of about 0.4 inches, the photon dose rate will be about $75 \%$ of the neutron dose rate at equal distances.

Current regulations for shipment under "Exclusive use conditions" state that the radiation level at three feet from the surface of the package is 1 imited to $10^{3} \mathrm{mrem} / \mathrm{hr}$, provided the radiation level does not exceed 200 $\mathrm{mrem} / \mathrm{hr}$ at the surface of the vehicle, $10 \mathrm{mrem} / \mathrm{hr}$ at six feet from the outside surface of the vehicle and $2 \mathrm{mrem} / \mathrm{hr}$ in the driver's or other normally occupied positions. Based on an array of containers, 4 wide by 10 long, each containing its maximum loading, $2.6 \mathrm{~kg}$ (1980) and $10 \mathrm{~kg}$ (production grade), a comparison is made in Figure 1 of the dose rates from low and high exposure plutonium. It can be seen that some shielding would have to be provided before one could transport this amount of 1980 material and that if larger heat loads could be accommodated, by container redesign, even more shielding (including that for neutrons) would be required.

In addition, the packaging of high exposure plutonium can be expected to require different procedures for packaging than production-grade plutonium. As an example, in the loading of the inner can (usually a thin-walled, 10 to $12 \mathrm{mil}$, steel can), the photon dose rates at the surface of the can will be about 2.9 and $0.3 \mathrm{rads} / \mathrm{hr}$ for 1980 and production grade 


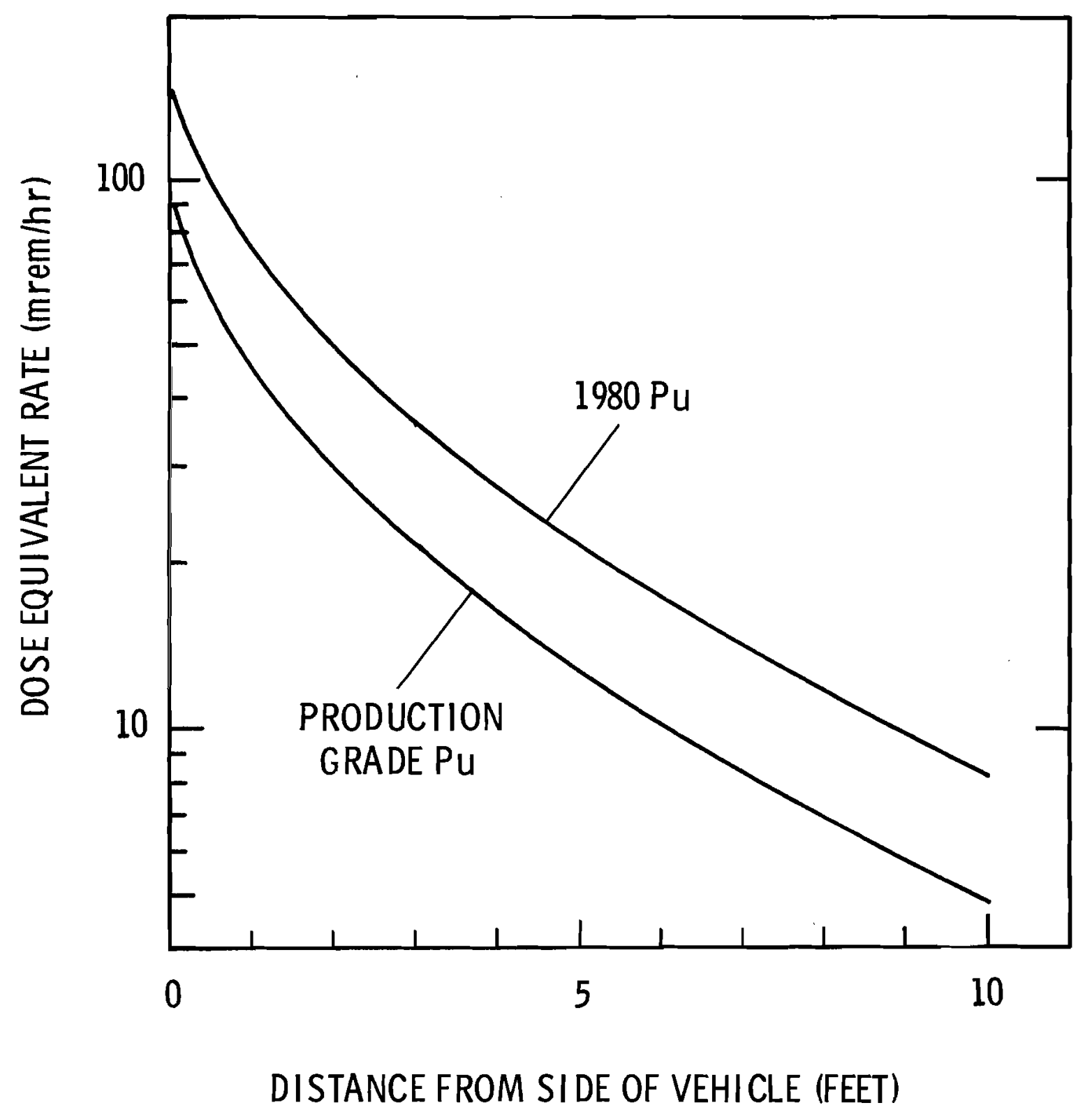

Figure 1. Dose Equivalent Rate from a $4 \times 10$ Array of Shipping Containers Each with $2.6 \mathrm{~kg}$ of $1980 \mathrm{Pu}$ or $10 \mathrm{~kg}$ of Production Grade Pu 
material, respectively. These values assume an age of one year for both materials. The use of $30 \mathrm{mil}$ lead loaded gloves will reduce these values by about a factor of three making a more manageable value for the 1980 material.

\section{Safeguards Considerations}

New measures may be taken in the near future to further reduce the possibility of plutonium diversion during transportation. Such measures could involve both packaging design and the design of the transportation vehicle. Packaging design changes could include such innovations as increasing packaging weight to reduce the mobility of individual packages and new package closure devices requiring special tools for opening, and thus reduce the possibility of unauthorized package opening.

Most measures, however, are likely to involve the transportation vehicle. Special trucks and trailers for exclusive hauling will probably come into use. Such trucks may have reinforced containment walls, installed locator equipment, and special features to prevent unauthorized entry. $(3,4)$

\section{CRITICALITY SAFETY CONSIIDERATIONS}

Limitations imposed on package and vehicle loadings for criticality safety will remain essentially the same as in the past. Slightly larger plutonium loadings may be realized by taking advantage of a lower fissile content $\left({ }^{239} \mathrm{Pu}+{ }^{241} \mathrm{Pu}\right)$ in high exposure plutonium, but the gain over present potentially allowable loadings will be small.

\section{ESTIMATE OF TRUCK CAPACITY FOR FUTURE PUO 2 POWDER SHIPMENTS}

To give an idea as to the potential capacity of a truck shipment of high exposure plutonium, the following illustration was developed. In this illustration allowance was given for possible new heat removal and radiation shielding features in the packaging and added safeguards features in the truck. No attempt was made to maximize the loading, however, so higher loadings could be justified by taking advantage of restricted plutonium 
geometry in the package design and by using a larger truck. Assumptions were as follows:

Packaging Size

24 in. $\times 24$ in. $\times 24$ in. Outside Dimensions

Truck Inside Dimensions

$6 \mathrm{ft}$ wide $\times 7 \mathrm{ft}$ high $x$ $24 \mathrm{ft}$ long

Truck Loading

108 packages

( $3 \times 3 \times 12$ - package array)

Fissile Class

Fissile Class III
This loading is based on the package and truck sizes assumed. Depending on truck bed dimensions and height, loadings could be larger or smaller.

This size allows space for new design features that may be forthcoming in future models, such as the addition of gamma and neutron shielding and a feature for heat dissipation.

The normal size truck is $8 \mathrm{ft}$ wide $x$ $9 \mathrm{ft}$ high and lengths range from 20$35 \mathrm{ft}$. The size selected al lows for thicker walls in the truck and thus a smaller compartment is assumed.

Most present day plutonium shipments are Fissile Class III, (exclusive use of vehicle), although the packages are Fissile Class II. Consequently, the illustration is based on Fissile class III shipments.

Based on the above assumptions, an allowable $\mathrm{PuO}_{2}$ powder loading was estimated for each package. This estimate was obtained in two ways: by using the array criticality calculations of J. T. Thomas ${ }^{(5)}$; and by using the subcritical array parameters reported in ANSI Standard N16.5 $(6)$. The calculations reported in these documents are based on spherical plutonium units in cubical arrays with full water reflection around each array. The steel and other materials of construction in each package provide sufficient neutron absorption to offset any effect of neutron moderation with in the array (i.e. between packages). Therefore, the values are expected to be applicable to the analysis of arrays of shipping packages. 
The results of the calculations with notes as to how the final values were derived are presented in Table 6 . Included in the table are values for plutonium from $80-100 \mathrm{wt} \%{ }^{239} \mathrm{Pu}$, and two degrees of moderation in the $\mathrm{PuO}_{2}(\mathrm{H} / \mathrm{Pu}$ of 0.4 and 3.0$)$.

It is concluded that depending on isotopic composition and degree of moderation, under the conditions assumed the allowable amount of plutonium per package could be on the order of $14 \mathrm{~kg}$. Thus, based on the assumed conditions, a truck loading could be about 1.5 MT plutonium. At a separations plant production rate of $50 \mathrm{~kg}$ Pu/day, a truck could thus safely hold about a months plutonium production and movement of 43 MT plutonium in 1985 would result in about 30 shipments.

The above illustration is very general. The amount of plutonium transported on a single truck could very well be limited to much less than 1.5 MT for other reasons, such as the dollar value of the shipment, safeguards, or neutron dose rates. (In fact, a 5-1/2 inch thick water-polymer neutron shield would be required in each shipping container to reduce the neutron dose equivalent rate to $10 \mathrm{mrem} / \mathrm{hr}$ at 6 feet from a truck containing 1.5 MT of $\mathrm{PuO}_{2}$. ) On the other hand, it is possible that package and truck loadings could be a factor of two or more higher by proper packaging design and allowing for a restricted geometry of the plutonium in a package. 
Table 6 - Estimated Allowable Pu0 2 Package Loading For 108 Packages Shipped As Fissile Class III

(Based on spherical units in cubical arrangement with full water reflection around array)

\section{Plutonium Isotopic \\ Composition, wt\%}

$239 \mathrm{Pu} \quad \underline{240 \mathrm{Pu}}$

100

100

$=94.8$

94.8

80

80$$
0
$$

0

5.2

5.2

20

20

\begin{tabular}{ll} 
H/Pu & \\
Atom & Density \\
Ratio & g Pu/cm 3 \\
\hline
\end{tabular}

\begin{tabular}{l} 
Number of \\
Packages in \\
Fissile Class \\
II I Shipment \\
\hline
\end{tabular}

\section{4}

3.0

8.7

4.7

0.4

8.7

4.7

8.7

4.7

Allowable Mass
Based on
Half the Number
of Packages
For Criticality (1)

13

12

15

14

16

17
Based on Allowable Number of Packages (2) Given In ANSI 16.5(2)

12
11
14
13
13
13
15
16

\footnotetext{
1. The amount of $\mathrm{PuO}_{2}$ per package for criticality in a 216 package array was selected from Reference 1 , Table 2 . Half of this number is 108 packages, the number allowed in the fissile Class III shipment.

2. The amount of $\mathrm{PuO}_{2}$ for the allowable number of packages (108) was obtained by interpolation from Reference 2 , Tables 5.7 - $5.10^{2}$.
} 


\section{REFERENCES}

1. Title 10 Part 71, "PACKAGING OF RADIOACTIVE MATERIAL FOR TRANSPORT AND TRANSPORTATION OF RADIOACTIVE MATERIALS UNDER CERTAIN CONDITIONS --- Form of Shipping Plutonium," Federal Register, Vol 39, No. 117, June 17, 1974.

2. G. H. Bryan and J. L. Ryan, "Solid Plutonium Shipping Forms," Transactions of 4th International Symposium on Packaging and Transportation of Radioactive Materials, Miami Beach, Fla., Sept. 22-27, 1974.

3. W. C. Barte1s, "Progress In Development Technology for Nuclear Materials Safeguards," Trans. Am. Nucl. Soc., 18, 184 (1974).

4. C. S. Sonnier, T. A. Sellers, J. M. de Montmollin, "Field Testing of a System for Communication With Commercial SNM Shipments," Trans. Am. Nuc1. Soc., 18, 185 (1974).

5. J. T. Thomas, "Criticality of Cubic Arrays of Fissile Material," Y-CDC-10, Oak Ridge Criticality Data Center, Oak Ridge, Tenn. (1971)

6. ANSI N16.5 - 1974, "Nuclear Criticality Safety In The Storage of Fissile Materials". 


\section{DISTRIBUTION}

No. of

Copies

OFFSITE

1

AEC Chicago Patent Group

U. S. Atomic Energy Commission

Argonne, IL 60439

A. A. Churm

1

AEC Division of Waste Management and Transportation

U. S. Atomic Energy Commission Washington, DC 20545

J. A. Sisler

124

AEC Technical Information Center

ONSITE

AEC Richland Operations Office

D. J. Squires

6

Hanford Engineering Development Laboratory

R. C. Smith (5)

J. N. Strode

44

Battelle-Northwest

L. W. Brackenbush (10)

C. L. Brown (10)

N. E. Carter

E. D. Clayton

G. W. R. Endres

L. G. Faust (10)

A. J. Haverfield

S. W. Heaberl in

W. S. Kelly

J. C. Nelson

J. K. Soldat

K. L. Swinth

Technical Files 